\title{
“KONSEP EKONOMI MERCANTILISME"
}

\author{
Oleh : Ainun Musfira (90100118005)
}

\section{Ainunmusfira56@gmail.com}

Konsep ekonomi adalah merupakan suatu konsep yang mengatur bagaimana memenuhi kebutuhan hidup baik sekarang maupun dimasa yang akan datang. Ekonomi bisa dikatakan mempunyai peranan yang sangat penting dan besar dalam sebuah negara. Bagaimana tidak, segala bentuk pembangunan yang dilakukan negara untuk masyarakat tidak terlepas dari perekonomian. Dalam diri setiap individu sangat membutuhkan ekonomi yang berkecukupan atau memadai untuk memenuhi kebutuhan hidup mereka. Tanpa adanya ekonomi kehidupan tidak bisa berjalan dengan baik, maka dari itu peranan ekonomi sangatlah besar didalam sebuh kehidupan berbangsa dan bernegara. ${ }^{1}$ Selanjutnya, konsep ekonomi merkantilisme adalah merupakan sebuah kebijakan ekonomi yang dominan dengan campur tangan dari pemerintah, politik kolonial, yang sifatnya menguntungkan bertdasarkan neraca perdagangan luar negeri. Bisa dikatakan kebijakan ekonomi dengan konsep ini bersifat makro.

Dengan membawa sebuah cara pandang ekonomi yang terkait dengan kesejahteraan negara, konsep merkantilisme ini muncul sekitar abad 18. Konsep ini berpandangan bahwa jika suatu negara ingin lebih maju, haruslah menjalin kerjasama dengan negara lain dari sektor perdagangan. Dengan adanya kerjasama ini kemudian akan menghasilkan sebuah surplus ekonomi dalam bentuk emas dan poerak dari perdagangan luar negeri.sehingga terjalin kerjasama yang baik dimana kelompok penguasa memiliki posisi yang penting dalam kehidupan masyarakat dan kerja sama yang dilakukan bisa lebih terjalin dengan baik. Sehingga secara tidak langsung keduanya bisa saling mendukung dalam hal monopoli perdagangan, dan kebebasan lainnya. Itulah mengapa kemudian abad ke 17 hingga 18 ini disebut seagai zaman kapitalisme yang berlangsung dikalnagan saudagar Eropa. ${ }^{2}$

Dasar pemikiran mercantilisme saat iti adalah segala hal yang terkaiit mekanisme arus logam mulia, neraca perdagangan dan teori kuantitas uang. Saat pemikiran ekonomi mercantilisme ini berkembang, ada beberapa negara tergabung dalam negara Eropa yang ikut menganut paham ini yaitu, Belanda, Portugis, Prancis, dan Inggris. Jika dilihat dari segi

${ }^{1}$ Siti Mujiatun, "Peran Pemerintah Tentang Pengembangan Perekonomian Dalam Perspektif Sistem Ekonomi Kappitalis, Sosialis dan Islam", Jurnal Analytica Islamica, Vol. 3 No. 1, 2014. HIm 91

2 Munif, Nasrulloh Ali, "Sistem Ekonomi Islam: Dialektika Antara Thesis, Antitesisi dan Plagiatis." IAIN Tulungagung Research Collections 2.1, 2015, HIm 325 
kuantitas maupun kualitas, pada masa ini perkembangan perekonomian bisa dikatakan sangat pesat dimana setiap manusia atau individu bisa menjadi ahli ekonomi bagi dirinya sendiri. ${ }^{3}$ Adapun tokoh pemikir ekonomi mercantilisme yaitu sebagai berikut :

1. Jean Bodin (1530-1596)

Jean Bodin adalah orang pertama yang memaparkan secara sistematis tentang tentang teori uang dan harga. Ia merupakan seorang ilmuwan yang berkebangsaan Prancis. Hal ini terdapat dalam bukunya yang berjudul Response aux Paradoxes de Malestroit tahun 1568. Menurutnya ada 5 faktor yang menyebabkan naiknya harga barang yaitu :

1) Bertambahnya emas dan perak yang termasuk logam mulia.

2) Adanya monopoli yang dilakukan swasta maupun dalam negara

3) Adanya pola hidup yang mewah dikalangan para penguasa dan bangsawan

4) Adanya ekspor, menyebabkan jumlah barang yang ada didalam negeri menjadi langka

5) Menurunnya nilai dari mata uang yang terjadi akibat kandungan karatnya dikurangi. ${ }^{4}$

2. Thomas Mun (1571-1641)

Thomas Mun adalah merupakan seorang saudagar kaya yang berkebangsaan Inggris. Beliau banyak menuliskan tentang masalah perdagangan luar negeri. England's Treasure by Foreign Trade adalah sebuah karyanya yang cukup terkenal terkait teori perdagangan luar negeri. Menurutnya, cara yang dapat dilakukan untuk meningkatkan kekayaan negara yaitu melalui perdagangan. Dengan adanya perdagangan akan memberikan keuntungan sekalipun ngara tidak mempunyai emas dan perak. Suatu negara yang meimiliki terlalu banyak uang malah justru akan tidak baik karena harga akan secara langsung naik dan akan merugikan serta mengurangi jumlah perdagangan. Dan hal ini akan mengurangi konsumsi dan juga permintaan. $^{5}$

3. Jean Baptis Colbert (1619-1683)

Adalah seorang pejabat negara yaitu seorang Menteri Utama dalam bidang ekonomi yang berkebangsaan prancis dalam pemerintahan raja Louis XIV.kebijakan yang dibuat Jean Baptis Colbert lebih mengarah kepada kejayaan dan kekuasaan negara. Dalam kekuasannya ia sangat mendorong perdagangan dan usaha dalam bidang kerajinan serta memperluas

${ }^{3}$ Fatkhur Rohman Albanjari, "Pemikiran Ilmu Ekonomi (Analisis Komparatif Ekonomi Masa Pra Klasik Dan Masa Rasulullah Saw): Fatkhur Rohman Albanjari.", Jurnal Ekonomi Syari'ah \& Bisnis Islam, Vol. 4 No.1, 2017, HIm 25

4 Firmansyah, "Buku Ajar : Mata Kuliah Sejarah Pemikiran Ekonomi", Departemen Pendidikan Nasional, Fakultas Ekonomi, Universitas Diponegoro, 2007, HIm 14

${ }^{5} \mathrm{lbid}, \mathrm{HIm} 15$ 
daerah jajahan prancis. Jean Baptis Colbert sangat menjamin hak monopoli kepada perusahaan untuk perdagangan natar negara dan munculnya perusahaan baru. ${ }^{6}$

4. Sir William Petty (1623-1687)

Sir William Petty adalah seorang ilmuan dan ekonom Inggris yang lahir pada 26 Mei 1623. Ia merupakan anggota Parlemen Inggris. Sebagai seorang ilmuwan dan akademis dari Oxford University, terdapat banyak buku yang ditulis oleh Sir yang berkaitan dengan ekonomi politik. Salah satu karyanya yaitu Political Arithmetic tahun 1676, buku yang memuat tentang metodologi ekonomi. Dengan buku ini statistika dikalangan masyarakat saat itu semakin berkembang. Dia adalah olorang pertama yang mengemukakan tentang nilai kerja dimana hal ini kurang dimengerti oleh ahli ekonom berikutnya. ${ }^{7}$

${ }^{6}$ Ibid, HIm 16

7 Ubaid Al Faruq \& Edi Mulyanto, "Sejarah Teori-Teori Ekonomi", (Tangerang Banten : UNPAM PRESS, 2017), HIm 44-46 


\section{DAFTAR PUSTAKA}

Al, Ubaid Faruq \& Edi Mulyanto. 2017. "Sejarah Teori-Teori Ekonomi”. (Tangerang Banten : UNPAM PRESS).

Firmansyah, 2007. "Buku Ajar : Mata Kuliah Sejarah Pemikiran Ekonomi”. Departemen Pendidikan Nasional, Fakultas Ekonomi, Universitas Diponegoro.

Mujiatun, Siti. 2014. "Peran Pemerintah Tentang Pengembangan Perekonomian Dalam Perspektif Sistem Ekonomi Kappitalis, Sosialis dan Islam”. Jurnal Analytica Islamica. Vol. 3 No. 1.

Munif, Nasrulloh Ali. 2015. "Sistem Ekonomi Islam: Dialektika Antara Thesis, Antitesis dan Plagiatis.". IAIN Tulungagung Research Collections 2.1.

Rohman, Fatkhur Albanjari. 2017. "Pemikiran Ilmu Ekonomi (Analisis Komparatif Ekonomi Masa Pra Klasik Dan Masa Rasulullah Saw): Fatkhur Rohman Albanjari.". Jurnal Ekonomi Syari'ah \& Bisnis Islam. Vol. 4 No.1. 